\section{Rootstock Affects Maturity of 'Starkspur Supreme Delicious' Apples}

\author{
Gerald R. Brown' and Dwight Wolfe ${ }^{2}$ \\ Department of Horticulture, University of Kentucky, Research and \\ Education Center, P.O. Box 469, Princeton, KY 42445
}

Additional index words. M alus domestica, ripening, flesh firmness, soluble solids

We determined the influence of nine rootstocks with 'Starkspur Supreme Delicious' apple (Malus domestica Borkh.) scions on maturity indices; percent fruit drop, soluble solids concentration (SSC), and flesh firmness. Rootstock can influence fruit maturity (Autio et al., 1991; Barden, 1988; Drake et al., 1988; Fallahi et al., 1985); however, the climate and soil in western Kentucky differ substantially from where most of the studies have been conducted.

As part of the NC-140 cooperative research, a planting of 'Starkspur Supreme Delicious' apple on the rootstocks M.7 EMLA, M.9 EMLA, M.26 EMLA, M.27 EMLA, M.9, MAC 9 (MARK), MAC 24, OAR 1, and Ottawa 3 was established in 1980 on a Tilsit silt loam at the Univ. of Kentucky Research and Education Center, Princeton, Ky. Experimental details have been reported by Autio et al. (1991).

Fruit drop, flesh firmness (penetrometer with a $1-\mathrm{cm}$ probe), and SSC (hand refractometer) over the 5 years from 1985-89 varied significantly among rootstocks (Table 1). Fruit drop and SSC were highest for trees on

Received for publication 19 Mar. 1991. Accepted for publication 6 Aug. 1991. Published with the approval of the Director of the Kentucky Agricultural Experiment Station as Paper no. 91-1035. This research was funded in part by the NC140 Regional Rootstock Project. The cost of oublishing this paper was defrayed in part by the payment of page charges. Under postal regulations, this paper therefore must be hereby marked $a d$ vertisement solely to indicate this fact.

'Extension Professor of Horticulture.

${ }^{2}$ Horticulture Research Specialist.
M.27 EMLA and least for trees on OAR 1. The firmest fruit were from trees on OAR 1, and the softest were from trees in Ottawa 3. However, the results for the four rootstocks noted did not differ significantly from all others.

Although fruit firmness was not correlated with either of the other two indices, fruit drop and SSC were correlated $(r=0.706)$. Fruit drop and SSC both were negatively correlated with cumulative yield $(r=-0.499$ and $r=-0.637$, respectively) and trunk cross-sectional area (TCSA; $r=-0,572$ and $r=-0.770$, respectively); flesh firmness was not correlated with either cumulative yield or TCSA. Cumulative yield efficiency (kilograms per TCSA) was significantly correlated with fruit drop $(r=$ $0.346)$, flesh firmness $(r=-0.398)$, and SSC $(r=0.383)$. Thus, in contrast to delayed maturity resulting from an excessive crop load, there was a slight tendency for fruit on trees with relatively heavier crop loads to mature sooner. Crop load, adjusted by hand thinning, and mean fruit weight $(185 \pm 11$ g) did not differ among rootstocks. Thus, there is no evidence to suggest that crop load delayed maturity in this study.

The maturity indices measured in this study were significantly influenced by rootstock, Although the specific rankings varied, this result agrees with those of other reports (Autio et al., 1991; Barden, 1988; Drake et al., 1988; Fallahi et al., 1985).

\section{Literature Cited}

Autio, W.R., J.A. Barden, and G.R. Brown. 1991. Rootstock affects ripening, size, mineral composition, and storability of 'Starkspur Supreme Delicious' in the 1980-81 NC-140 cooperative planting. Fruit Var. J. (In press.)

Barden, J.A. 1988. Rootstock effects on maturity, quality, storage life, and physiological disorders of Delicious apples. Compact Fruit Tree 21:82-85.

Drake, S.R., F.E. Larsen, J.K. Fellman, and S.S. Higgins. 1988. Maturity, storage quality, carbohydrate, and mineral content of 'Goldspur' apples as influenced by rootstock. J. Amer. Soc. Hort. Sci. 113:949-952.

Fallahi, E., D.G. Richardson, and M.N. Westwood. 1985. Quality of apple fruit from a high density orchard as influenced by rootstocks, fertilizers, maturity, and storage. J. Amer. Soc. Hort. Sci. 110:71-74.

Table 1. Effect of rootstock on fruit drop, flesh firmness, and soluble solids concentration (SSC) of 'Starkspur Supreme Delicious' at harvest, 1985-89.

\begin{tabular}{llcc}
\hline & $\begin{array}{c}\text { Fruit } \\
\text { drop } \\
\text { Rootstock }\end{array}$ & $\begin{array}{c}\text { Flesh } \\
\text { firmness } \\
(\%)\end{array}$ & $\begin{array}{c}\text { SSC } \\
(\%)\end{array}$ \\
\hline M.27 EMLA & $41.2 \mathrm{a}$ & $71.9 \mathrm{bc}$ & $15.1 \mathrm{a}$ \\
MAC 9 (MARK) & $38.9 \mathrm{ab}$ & $74.2 \mathrm{bc}$ & $14.6 \mathrm{ab}$ \\
M.9 EMLA & $36.1 \mathrm{abc}$ & $73.4 \mathrm{bc}$ & $14.3 \mathrm{ab}$ \\
Ott.3 & $23.2 \mathrm{c}$ & $70.1 \mathrm{c}$ & $13.9 \mathrm{bc}$ \\
M.9 & $29.0 \mathrm{abc}$ & $75.1 \mathrm{ab}$ & $13.8 \mathrm{bcd}$ \\
M.7 EMLA & $25.9 \mathrm{bc}$ & $72.2 \mathrm{bc}$ & $13.1 \mathrm{~cd}$ \\
OAR 1 & $21.7 \mathrm{c}$ & $78.9 \mathrm{a}$ & $13.1 \mathrm{~cd}$ \\
M.26 EMLA & $26.9 \mathrm{bc}$ & $71.6 \mathrm{bc}$ & $13.1 \mathrm{~cd}$ \\
MAC 24 & $24.1 \mathrm{c}$ & $73.3 \mathrm{bc}$ & $12.8 \mathrm{~d}$ \\
\hline
\end{tabular}

In ascending order of 1989 trunk cross-sectional area $25 \mathrm{~cm}$ above the graft union.

yWeight of fruit dropped as a percent of total yield.

'Mean separation within columns by Duncan's multiple range test $(P<0.05)$. 